\title{
Investigations of the Ultimate and Proximate Analysis of Coal Samples From the Singrauli Coalfield, India
}

\author{
Ankur Dwivedi ${ }^{1}$, Amarendra Kumar ${ }^{2}$ \\ ${ }^{1} \mathrm{PhD}$ scholar, Department of Mining Engineering IIT (BHU), Varanasi-221005 \\ ${ }^{2}$ Associate professor, Department of Mining Engineering IIT (BHU), Varanasi-221005
}

\begin{abstract}
Coal is a mixture of heterogeneous sedimentary rock materials; it includes organic and inorganic constituents. The utilisation potential of any coal depends on its chemical constituents, and the gross calorific value defines its usefulness in thermal power generation and other industries. In this study, we collected non-coking coal from the Singrauli coalfields region in India. These coals have been analysed for proximate and ultimate analysis and GCV (gross calorific value). The grade of coal varies from G6 to G9. De-ashing and clean coal technology are required. This study will reveal the reasons for grade variation in coal, which will be useful in thermal power industries.
\end{abstract}

KEYWORDS: Coal, Gondwana Basin, Proximate Analysis, Ultimate Analysis

\section{INTRODUCTION}

Different types of coal have been used as a source of energy for power generation all over the world. Coal is a combustible sedimentary rock, black or brownish black in colour, mostly made up of carbon components like macerals and a range of other mineral components in various phases.[1]. Coal is produced in a variety of nations and is used in a variety of industries, including electricity generation and metallurgical application in the steel industry. Along with China, the United States, Indonesia, and Australia, India is one of the world's leading coal producers. According to geological survey of India reports, the coal reserves in India are around 308.802 billion tons, up to the depths of 1,200 meters. Coal consumption is steadily expanding to meet global energy demands. Coal is made by the bacterial decomposition of plant elements such lignin, cuticle bark, and stems, and it is carried and deposited in various basins by water. Coal is made through the bacterial decomposition of the organic elements such lignin, cuticle, bark, and stems, and it is transported by water and deposited in various basins around the planet over time[2]. Many additional industries, such as limestone, alumina smelting, coke production, cement manufacturing, copper ore smelting, and metallurgical industries, rely on coal-fired power generation. It's also employed in a variety of chemical industries, as well as the creation of several nitrogenous fertilizers like urea. Coal is a solid, hard material made up of organic and inorganic chemicals that was formed by heat and overlying pressure. It is a non-renewable energy source that releases a variety of hazardous gases into the atmosphere when burned[3].Coal comes in a variety of forms. Opencast and underground mining processes are used to mine coal, as well as peat, lignite, bituminous, and anthracite around the world. It is generally found in a sedimentary formation known as a seam, where vegetation has accumulated over time and has experienced chemical and physical changes. Coal transformation processes include decay, deposition and burying by sedimentation, compaction, and the transformation of plant materials into organic rock in the form of coal. [4].

Geochemically, the type of the plant components deposited in coal varies around the world. Its rank is determined by the degree of metamorphism or coalification, and its grade is determined by the range of impurities present. Despite these advantages, coal byproducts like fly ash and bottom ash pollute the air, water, and land, lowering the aesthetic value of the impacted locations. As a result, in the current circumstances, ecologically responsible management is required. Clean coal technology (CCT), which is a set of technologies being developed to minimize the environmental consequences of coal energy, will also be discussed in this study. Coal is a critical energy source for many countries, and it is transformed into heat and electricity using various technologies to meet our everyday needs. As a result, determining coal quality is a critical undertaking that requires knowledge of the coal's physical and chemical makeup. This research could be utilized as the foundation for future coal-related problems. [5]. This research could be utilized as a foundation for future concerns regarding coal trading and utilization. Proximate and ultimate coal analyses are being 


\section{International Journal of Current Science Research and Review}

ISSN: 2581-8341

\section{Volume 05 Issue 01 January 2022}

DOI: 10.47191/ijcsrr/V5-i1-23, Impact Factor: 5.825

IJCSRR@ 2022

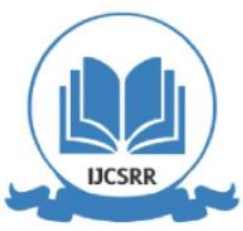

www.ijesrr.org

carried out in the current investigation. This coal was mined at the Singrauli coalfield. The current research is based on the chemical and physical properties of coal. The quantity of thermal energy (gross calorific value) determines its grade.

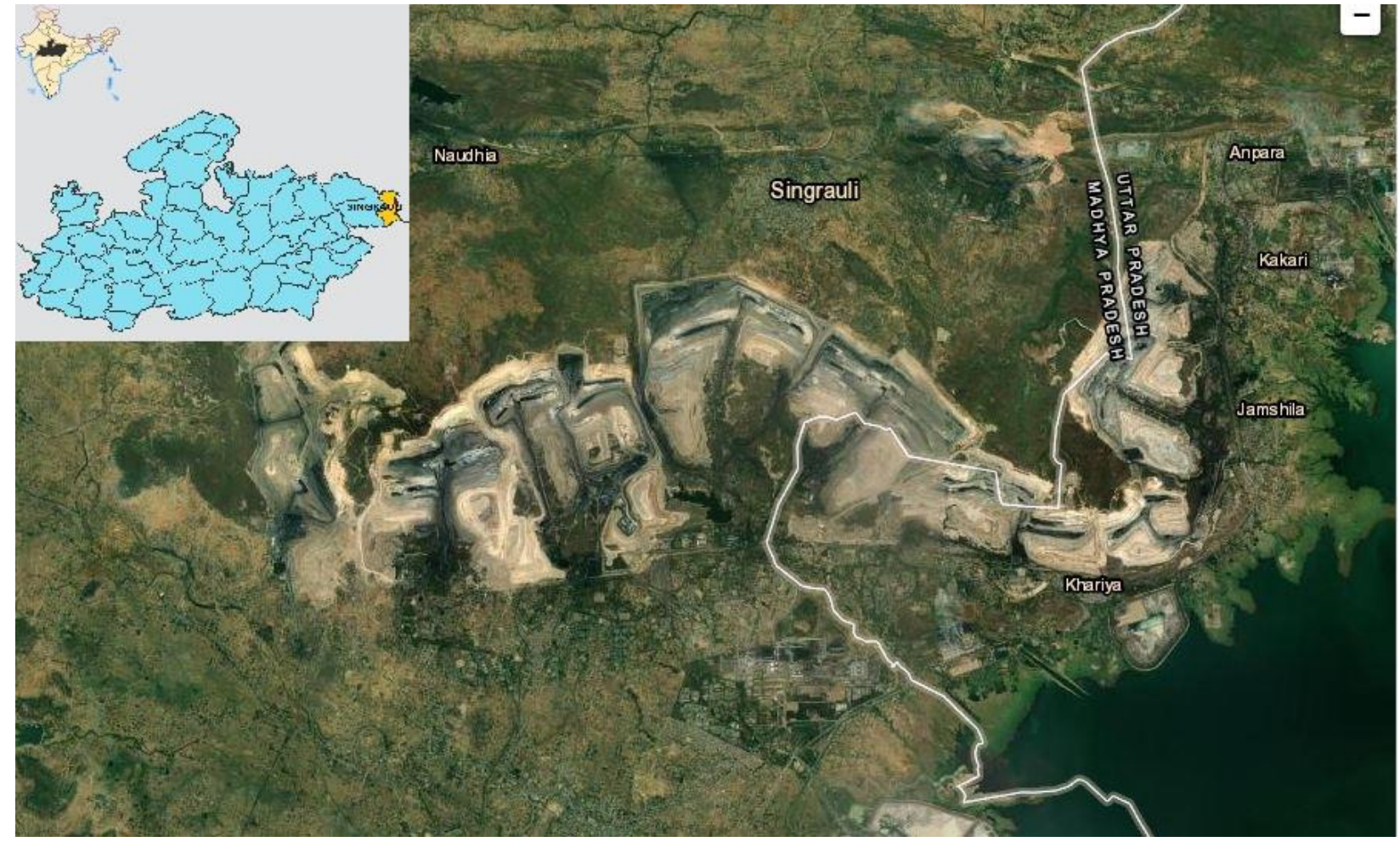

Fig1. Location of different mines in Singrauli coal field

\section{MATERIALS AND METHODS}

A. collection and preparation coal Sample

The samples of coal have been collected from the Singrauli coalfield, located in the Singrauli district, India. These coalfields are located in the central part of India. These coal mines are opencast mines situated in the north eastern part of the Gondwana basin. Coal samples were collected in the post monsoon period in the month of December, so that moisture was in situ in nature. These samples were collected by the pillar sampling method; samples were collected from a mine seam known as the Turra seam. Coal samples were collected and labelled as, CL1, CL2, CL3, CL4, and CL5, respectively. The collected coal samples were put in plastic bags and sealed immediately to reduce oxidation and any other contamination. After the collection of samples, they were crushed in a ball mill and sieved with a filter of -212 microns size for further investigations.

B. Proximate and ultimate analysis determination:

The proximate analysis is used for the estimation of coal quality, which is helpful in thermal industries. It includes the determination of moisture, volatile matter (VM), ash and fixed carbon (FC), present in coal in weight percentage. This method is widely used for industrial purposes as well as for the grading of coal. For the analysis of moisture content in coal, a sample of one gram of air-dried coal ( -212 microns IS) sieved sample was taken in the silica dish and heated up to a temperature of $108^{\circ} \pm 2^{\circ} \mathrm{C}$ in a closed oven. The difference in the amount of weight before and after heating was taken as the content of moisture in the coal. The moisture is present in the form of inherent and surface moisture. The physically and chemically bonded moisture in the coal decomposes after heating at $108^{\circ} \pm 2^{\circ} \mathrm{C}$.

Ash is formed by the complete combustion of inorganic mineral matter present in coal. For ash estimation in the coal, one gram of air dried, sieved coal (-212 microns in size) was taken in a porcelain dish. In the porcelain dish, coal should be present in a very thin layer and be heated in the muffle furnace. The muffle furnace temperature was raised up to $500^{\circ} \mathrm{C}$ in thirty minutes and then again raised to $815^{\circ} \mathrm{C}$ for another 30 to 60 minutes. This temperature was maintained for another 60 minutes. After that, the dish was 


\section{International Journal of Current Science Research and Review}

ISSN: 2581-8341

Volume 05 Issue 01 January 2022

DOI: 10.47191/ijcsrr/V5-i1-23, Impact Factor: 5.825

IJCSRR@ 2022

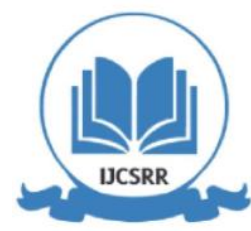

www.ijesrr.org

taken out of the muffle furnace.Then the loss in the weight was calculated and expressed as the percentage of ash present in the coal. For the analysis of volatile matter in coal, each sample of 1 gram of air-dried coal (ground to pass through a -212 microns IS sieve) was taken into a crucible with a lid and placed in the muffle furnace, which was already at a temperature of 900 for a period of 7 minutes. Then the differences in the weight loss were calculated before and after heating. The data was expressed in the form of the weight percentage of the coal samples (ASTM D5142). The ultimate analysis is used for the determination of C (carbon), $\mathrm{H}$ (hydrogen), S (sulphur), $\mathrm{N}$ (nitrogen) and O (oxygen) in elemental form present in coal by using the instrument Euro 3000 Elemental Analyzer.

For estimation of the GCV, we used an oxygen bomb calorimeter, the Parr 6100 Series. A bomb calorimeter measures the heat of combustion of a particular material under set conditions. A bomb was prepared with $\mathrm{Ni}-\mathrm{Cr}$ fuse wire for GCV calculation. A onegram coal sample was taken for the analysis (ASTM D5865).)[6].

\section{RESULT AND DISCUSSIONS}

Table 1. Proximity analysis calculations

\begin{tabular}{|l|l|l|l|l|l|}
\hline Sample no. & Moisture $(\%)$ & Volatile matter $(\%)$ & Ash $(\%)$ & Fixed carbon $(\%)$ & GCV \\
\hline CL1 & 5.00 & 28.60 & 15.00 & 51.40 & 5630 \\
\hline CL2 & 6.00 & 30.00 & 15.00 & 49.00 & 5521 \\
\hline CL3 & 7.00 & 30.00 & 20.10 & 42.90 & 4830 \\
\hline CL4 & 6.10 & 28.00 & 23.00 & 42.90 & 4920 \\
\hline CL5 & 4.50 & 31.10 & 20.00 & 44.40 & 5280 \\
\hline
\end{tabular}

Table 2. Ultimate analysis calculations

\begin{tabular}{|l|l|l|l|l|l|l|l|l|}
\hline Sample no. & Nitrogen $(\%)$ & Carbon(\%) & Hydrogen(\%) & Sulfur(\%) & Oxygen(\%) & H/C & O/C \\
\hline CL1 & 1.76 & 62.81 & 3.88 & 0.22 & 16.33 & 0.06 & 0.26 \\
\hline CL2 & 1.71 & 60.84 & 3.84 & 0.33 & 23.84 & 0.06 & 0.39 \\
\hline CL3 & 1.17 & 55.37 & 4.86 & 0.92 & 21.08 & 0.88 & 0.38 \\
\hline CL4 & 0.72 & 51.18 & 3.40 & 0.39 & 29.31 & 0.67 & 0.57 \\
\hline CL5 & 1.42 & 40.46 & 2.82 & 0.70 & 28.36 & 0.67 & 0.70 \\
\hline
\end{tabular}

Table 1represents the proximate analysis characteristics of different coal samples. The coal CL1 has low volatile matter (28.60 wt $\%$ with $15.00 \mathrm{wt} \%$ of ash). It shows high fixed carbon at $51.40 \mathrm{wt} \%$. The moisture content is moderate in this coal. The presence of aliphatic and aromatic compounds in coal derived from the lignin cuticle and hard wood portion of plant parts during deposition enriches its carbon content. Burning of such coal substances releases harmful gases into the environment [7]. In CL2, total ash is $15.00 \mathrm{wt} \%$, moisture is $6.00 \mathrm{wt} \%, \mathrm{VM}$ is $30.00 \mathrm{wt} \%$, and FC is $49.00 \mathrm{wt} \%$. It has low ash content due to the dominance of organic components. As a result, it contributes to coal's GCV.In CL3; proximate analysis revealed that it contained $42.90 \mathrm{wt} \%$ of FC, 7.00 $\mathrm{wt} \%$ of moisture, and VM of $30.0 \mathrm{wt} \%$. There is a lot of moisture in this coal, and it comes in two forms, free moisture and inherent moisture. Moisture content in this coal, formed when the seam comes in contact with water or through various sources of cleavage, fissures, and cracks developed in coal, might increase the moisture content of coal. The high volatile and moisture content present in coal leads to a decrease in the GCV and power generation potential. The moisture content present in coal plays a very important role which can greatly affect the burning characteristics of coal. Due to endothermic evaporation, moisture content affects both the internal temperature condition within the solid materials and the total energy that is required to bring the solid up to the pyrolytic temperature. The moisture content of the CL3 was recorded as having the highest value of $7.0 \mathrm{wt} \%$. In proximate analyses, the FC of CL4 is $42.9 \mathrm{wt} \%$, the moisture is $6.10 \mathrm{wt} \%$, the VM is $28.0 \mathrm{wt} \%$, and the ash is $23.0 \mathrm{wt} \%$. The high ash content in this coal is due to terrigenous mineral material derived during the deposition phase from more silica, alumina, and other clay-rich minerals. Coal's volatile content contributes to its calorific value and energy efficiency. Mineral matter in coal is generated by different factors, including detritus input and precipitation of minerals during and after peat formation.[8].

$\mathrm{FC}$ is $44.40 \mathrm{wt} \%$, as is his $20.00 \mathrm{wt} \%$, volatile matter is $31.10 \mathrm{wt} \%$, and moisture is $4.50 \mathrm{wt} \%$ in coal CL5.Low moisture and high carbon content give this coal good energy efficiency. Low moisture and VM support the release of heat. In the process of coal 


\section{International Journal of Current Science Research and Review}

ISSN: 2581-8341

Volume 05 Issue 01 January 2022

DOI: 10.47191/ijcsrr/V5-i1-23, Impact Factor: 5.825

IJCSRR@ 2022

WWw.ijesrr.org

burning, carbon, hydrogen, and oxygen elements of coal when heated, turn into vapors, which are typically a mixture of various short and long-chain hydrocarbons, which are called volatile matter. Volatile content has been shown to influence the thermal characteristics of solid fuels, but this is also governed by the structure and bonding present within the fuel.

The ultimate analysis of the collected coal samples is presented in Table 2. It can be seen that coal CL-1 contains carbon (62.81wt $\%$ ), hydrogen $(3.88 \mathrm{wt} \%)$, nitrogen $(1.76 \mathrm{wt} \%)$, sulphur $(0.22 \mathrm{wt} \%)$, and oxygen $(16.33 \mathrm{wt} \%)$ in plant matter, which contribute to the fixed carbon percentage in coal [9]. The results of CL 2 indicate the presence of carbon (60.84wt\%), hydrogen (3.84wt $\%)$, nitrogen $(1.71 \mathrm{wt} \%)$, sulphur $(0.33 \mathrm{wt} \%)$, and oxygen $(23.84 \mathrm{wt} \%)$. Ash has a crucial role in the heat transfer mechanism to the surface of the fuel as well as the dispersion of oxygen onto the fuel surface during char combustion. The values of volatile matter and ash content observed in this study are good and acceptable for thermal power generation purposes. In CL-3, carbon (55.37wt \%), hydrogen (4.86 wt \%), oxygen (21.08 wt \%), nitrogen (1.17 wt \%) CL-4 coal contains 51.18wt\% carbon, $0.72 \mathrm{wt} \%$ hydrogen, and $29.31 \mathrm{wt} \%$ oxygen. $0.72 \mathrm{wt} \%$ nitrogen high oxygen content $(17.69 \mathrm{wt} \%)$ reveals the toxic condition during coal deposition in the fresh water environmental conditionCL-5 denotes carbon (40.46 weight percent), hydrogen (2.82 weight percent), oxygen (28.36 wt \%), and nitrogen (1.42 wt \%).Sulphur0.70 wt \% is seen as moderate in nearly all five coal samples in comparison to other highsulphur coal in India.

The H/C ratio of CL3 is 0.88 , which is high as compared to the rest of the coal, because carbon maturation is lower in this coal. The $\mathrm{O} / \mathrm{C}$ ratio of CL4 is high at 0.70 as compared to other coal types; it represents the oxygenic condition during coal formation. [2].

According to BIS, CL 1 and CL 2 are in the G6 category, CL 3 is in the G9 category, CL 4 is in the G8 category, and CL 5 is in the G7 category of non-cocking coal. Coal is an indispensible source of energy. The combustion of coal produces many environmentally harmful gases through the burning of inorganic and organic constituents. [10, 11].

The current high energy demand needs good management and CCT to efficiently reduce the pollutant loads. De-ashing of Indian bituminous coal and bio remediation techniques to reduce ash content. CCT's main objective is to remove mineral matter, especially ash, from the coal as fusion causes slugging, abrasion, and fouling in the furnaces and leaches minerals into the environment that are bio-available to plants and humans, which is not good for health..

From the laboratory result analysis, specifically from the estimated percentage of carbon and calorific value amounts, coal ranks were determined to be lignite to sub bituminous and medium to highly volatile in nature. Several physicochemical parameters were examined, and these parameters have a direct correlation with coal's energy generation efficiency. The calorific value, determines the energy content of coal. It is a property of coal that depends on its chemical constituents and moisture content. The most important property of a fuel is its GCV..[11].

\section{CONCLUSION}

The detailed estimation of the proximate, ultimate, and GCV from these collected from Singrauli Colliery gives a good understanding of the mode of occurrence of mineral matter, fixed carbon, and its origin and end-specific use. CL 1 has the highest GCV, while CL 3 has the highest moisture, which affects the GCV potential of coal. CL 3 has 0.92 wt of sulfur. Other parameters are moderate. The $\mathrm{HC}$ ratio is highest in CL3, i.e., 0.88 , and the $\mathrm{O} / \mathrm{C}$ ratio is 0.7 for coal CL5. The coals of this mine are bituminous in nature, which reflects a low level of sulphur content, so their origin is in a fresh water environment. The lower ash content found in CL 4 and CL 5 might find use in the metallurgical industries. Benefited coal can be mixed with coke in a blast furnace, as well as other suitable coals, to generate power in thermal industries.

\section{ACKNOWLEDGEMENT}

The authors are thankful to Department of Mining Engineering IIT(BHU) Varanasi, for providing necessary facility, and financial support to conduct these experiments.

\section{REFERENCES}

1. Mishra, U., Environmental impact of coal industry and thermal power plants in India. Journal of environmental radioactivity, 2004. 72(1-2): p. 35-40.

2. Cheng, Q., et al., The contribution of bacteria to organic matter in coal-measure source rocks. Acta Geochimica, 2019. 38(3): p. 364-375. 


\section{International Journal of Current Science Research and Review}

ISSN: 2581-8341

Volume 05 Issue 01 January 2022

DOI: 10.47191/ijesrr/V5-i1-23, Impact Factor: 5.825

IJCSRR@ 2022

www.ijcsrr.org

3. Qaisar, S.H. and M.A. Ahmad, Production, consumption and future challenges of coal in India. International Journal of Current Engineering and Technology, 2014. 4(5): p. 3437-40.

4. Kershaw, J.R. and G.H. Taylor, Properties of Gondwana coals with emphasis on the Permian coals of Australia and South Africa. Fuel Processing Technology, 1992. 31(2): p. 127-168.

5. Sahu, S., et al., Characterization and quantification of persistent organic pollutants in fly ash from coal fueled thermal power stations in India. Microchemical Journal, 2009. 92(1): p. 92-96.

6. ASTM, D., 3175-89, Standards Test Method for Volatile Matter in the Analysis Sample of Coal And Coke. Gaseous Fuels, Coal and Coke, 1989: p. 05-05.

7. Solomon, P.R. and R.M. Carangelo, FT-ir analysis of coal: 2. Aliphatic and aromatic hydrogen concentration. Fuel, 1988. 67(7): p. 949-959.

8. Dianshi, D., et al., Characteristics of the coal quality and elemental geochemistry in Permian coals from the Xinjier mine in the Huainan Coalfield, north China: Influence of terrigenous inputs. Journal of Geochemical Exploration, 2018. 186: p. $50-60$.

9. Song, Y., et al., Depositional environment of the Lower Cretaceous Muling Formation of the Laoheishan Basin (NE China): Implications from geochemical and petrological analyses. Organic geochemistry, 2017. 104: p. 19-34.

10. Chakravarty, S., et al., Characterization of Chemical Structure with Relative Density of Three Different Ranks of Coal from India. Natural Resources Research, 2020. 29(5): p. 3121-3136.

11. Hou, T., et al., Outlook of deashing of high-ash and difficult-to-float tiny coals. Clean coal technology, 2008. 14: p. 18-20.

Cite this Article: Ankur Dwivedi, Amarendra Kumar (2022). Investigations of the Ultimate and Proximate Analysis of Coal Samples From the Singrauli Coalfield, India. International Journal of Current Science Research and Review, 5(1), 198-202 